\title{
Evaluasi Program Ujian Akhir Semester (Uas) Virtual Model Cipp (Context, Input, Process, Product) Di Iainu Kebumen Tahun Akademik 2019/2020
}

\author{
Imam Subarkah \\ barkah44@gmail.com \\ Atim Rinawati \\ atimrinawati87@gamil.com \\ Dosen IAINU Kebumen
}

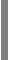

\author{
Ifa Munawaroh \\ ifamunawaroh76@gmail.com \\ Mahasiswa IAINU Kebumen \\ , dan \\ email:, ,
}

Abstrak:

Penelitian ini bertujuan untuk mengetahui: 1) Untuk mengetahui bagaimana tahapan evaluasi program UAS virtual di Perguruan Tinggi IAINU Kebumen dengan model CIPP. 2) Untuk Mengetahui Efektivitas dan efisiensi dari pelaksanaan UAS virtual di IAINU Kebumen.

Penelitian ini merupakan penelitian evaluasi (evaluation research) dengan objek penelitian penyelenggaraan program Ujian Akhir Semester (UAS) Virtual pada Perguruan Tinggi IAINU Kebumen, yang dilaksanakan oleh seluruh fakultas di IAINU Kebumen. Sumber data dalam penelitian ini adalah Wakil Rektor 1 bidang Akademik dan Kemahasiswaan, Koordinator pelaksanaan UAS Virtual dan Mahasiswa yang menjadi peserta UAS Virtual perdana pada tahun 2019 di Perguruan Tinggi IAINU Kebumen. Mahasiswa yang dijadikan sampel dengan teknik Cluster Random Sampling, model evaluasi yang digunakan adalah model evaluasi CIPP dengan metode evaluasi kuantitatif. Pengumpulan data diambil melalui kuesoner, wawancara dan dokumentasi. Analisis data menggunakan statistik deskriptif dan disajikan dalam bentuk tabel dan histogram.

Hasil dari penelitian ini adalah tahapan evaluasi program yang dilakukan oleh peneliti disesuaikan dengan prosedur evaluasi program, yaitu tahap perencanaan, tahap pelaksanaan, tahap monitoring, tahap analisis data penafsiran dan tahap penyusunan rekomendasi. Setelah proses analisis data selesai dilaksanakan diperoleh hasil penelitian yang menunjukkan bahwa evaluasi program UAS virtual di IAINU Kebumen Tahun Akademik 2019/2020 adalah sebagai berikut: persentase evaluasi terhadap context menunjukkan hasil yang tergolong baik dengan persentase $75,20 \%$, persentase evaluasi terhadap input menunjukkan hasil yang tergolong baik yaitu $68,37 \%$, persentase evaluasi terhadap process menunjukkan hasil yang tergolong baik yaitu $71,50 \%$, persentase evaluasi terhadap product menunjukkan hasil yang tergolong baik yaitu $73,28 \%$. Berdasarkan hasil penelitian tersebut dapat disimpulkan bahwa pelaksanaan UAS virtual ditinjau dari keseluruhan aspek yaitu context, input, process, product tergolong baik dengan hasil persentase $72,09 \%$. Berdasarkan persentase tersebut pelaksanaan UAS virtual dapat dikatakan efektif dan efisien. Jadi, rekomendasi yang dapat penulis berikan kepada pembuat keputusan yaitu (1) meningkatkan sarana dan prasarana penunjang UAS virtual; (2) meminimalisir terjadinya 
gangguan dalam sistem yang digunakan sebagai media UAS virtual; (3) meningkatkan keamanan jawaban supaya tidak terjadi plagiasi.

Kata Kunci: Evaluasi Program, UAS virtual, CIPP

\section{A. Pengantar}

Pengaruh Revolusi Industri 4.0 bagi Perguruan Tinggi sudah tidak dapat terhindarkan lagi. Hal ini terjadi bersamaan dengan munculnya MOOCs (Massive Open Online Courses) yang mengawali disrupsi di perguruan tinggi dan bahkan seluruh sistem pendidikan tinggi. ${ }^{12}$ Dampak dari munculnya MOOCs, pelaksanaan pendidikan di Perguruan Tinggi semakin mengarah pada sistem online, dari sistem online tersebut saat ini sudah bermunculan Perguruan Tinggi yang menggunakan sistem pembelajaran jarak jauh (PJJ) yang di dalamnya sering kita kenal dengan istilah e-learning (electronic learning). E-learning adalah pembelajaran jarak jauh yang menggunakan teknologi komputer, atau biasanya disebut internet. ${ }^{13}$ Pengertian dari internet itu sendiri yaitu sebuah jaringan besar yang terdiri dari berbagai jaringan yang meliputi jaringan pendidikan dan penelitian serta menghubungkan jutaan komputer di dalam jaringan-jaringan tersebut. $^{14}$

Kata virtual dimaknai oleh Perguruan Tinggi IAINU Kebumen yaitu memiliki kemampuan dalam teknologi digital di era 4.0. ${ }^{15}$ Dalam rangka menuju visi virtual tersebut, pada Ujian Akhir Semester (UAS) gasal kemarin, pada bulan Januari 2020 untuk pertama kalinya melaksanakan Ujian Akhir Semester (UAS) perdana paperless. Keberanian tersebut menjadikan IAINU sebagai kampus virtual pertama di Kebumen, bahkan di Jawa Tengah. Tidak hanya itu saja, pada awal semester genap tahun akademik 2019/2020 sudah diberlakukan program pembelajaran secara virtual di kelas.

Penilitian ini berupaya mengetahui keterlaksanaan Program Ujian Akhir Semester (UAS) virtual tahun akademik 2019/2020 dan mengapa Perguruan Tinggi IAINU kebumen memberanikan diri bertransformasi menjadi Perguruan Tinggi berbasis virtual.

\section{B. PEMBAHASAN}

\section{Ujian Akhir Semester (UAS) Virtual}

Pengertian dari ujian akhir semester adalah ujian yang diberikan di perguruan tinggi pada waktu perkuliaahan berakhir dalam setiap semester. ${ }^{23}$ Mengutip dari Visi IAINU Kebumen, kata virtual artinya proses manajerial, pembelajaran, dan informasi melalui cyberspace dan memanfaatkan teknologi digital. ${ }^{24}$ Jadi berdasarkan pengertian di atas, UAS virtual dapat didefinisikan

\footnotetext{
12) May Oey-Gardiner, Mayling \& Dkk. (2017). Era Disrupsi Peluang dan Tantangan Pendidikan Tinggi Indonesia. Jakarta: Akademi Ilmu Pengetahuan Indonesia.hal. 15

${ }^{13)}$ Hujair AH Sanaky. Media Pembelajaran Interaktif-Inovatif. (Yogyakarta: Kaukaba Dipantara, 2013). hal. 238

14) Munir. Pembelajaran Digital. (Bandung: Alfabeta, 2017). hal. 37

15) Keputusan Rektor Pedoman Umum Pembinaan Organisasi Kemahasiswaan IAINU Kebumen tahun 2020 [
} 
sebagai proses pelaksanaan ujian di perguruan tinggi pada waktu perkuliahan berakhir dalam setiap semester dengan cara memanfaatkan teknologi digital.

Ujian Akhir Semester (UAS) virtual merupakan bagian dari implementasi konsep pendidikan jarak jauh (distance learning). Sesuai dengan namanya, program UAS virtual di IAINU Kebumen dilaksanakan secara Online. Berdasarkan keterangan yang tertera dalam jadwal UAS genap tahun ajaran 2019/2020, dosen melaksanakan UAS virtual secara mandiri sesuai dengan jadwal yang telah ditentukan dengan menggunakan aplikasi: google classroom, Google Form, Google Drive, Whatsapp atau via E-Mail. Model evaluasi yang digunakan ialah evaluasi model CIPP.

\section{Metodologi Penelitian}

Populasi dalam penelitian ini yaitu mahasiswa yang terdapat di Perguruan Tinggi IAINU Kebumen meliputi seluruh mahasiswa aktif IAINU Kebumen yang ada di semester 2, 4, dan 6 dari ketiga fakultas yaitu Fakultas Tarbiyah, Fakultas Ekonomi dan Bisnis Islam (FEBI) dan Fakultas Syari'ah Ushuluddin dan Dakwah (FSUD) yang pernah mengikuti UAS virtual, Jumlah sampel yang diambil dalam populasi, peneliti mengacu pada tabel penentuan jumlah sampel dari populasi tertentu yang dikembangkan oleh Isaac dan Michael untuk ukuran sampel tingkat kesalahan $10 \%$ dengan populasi 1.000 sampel yang dibutuhkan yaitu 213. ${ }^{11}$ Cara pengambilan sampel dilakukan peneliti menggunakan kuesioner tertutup dengan kriteria sampel adalah mahasiswa aktif yang mengikuti UAS virtual Tahun Akademik 2019/2020. Skala yang digunakan dalam penelitia ini adalah skala likert, yaitu skala yang pada prinsip pokoknya menentukan lokasi kedudukan seseorang dalam suatu kontinum sikap terhadap objek sikap, mulai dari sangat negatif sampai dengan sangat positif. ${ }^{13}$ Dalam penelitian ini yang menjadi responden dalam pengisian angket adalah mahasiswa aktif yang mengikuti UAS virtual Tahun Akademik 2019/2020 yang dijadikan sampel sebanyak 15\% mahasiswa aktif yang pernah mengikuti UAS.

Pengujian reliabilitas dalam penelitian ini menggunakan uji reliabilitas internal dengan berdasarkan pemberian skor instrumen yaitu dengan metode instrumen skor non diskrit. Instrumen non diskrit ini analisis reliabilitasnya menggunakan rumus Alpha.

\section{HASIL PENELITIAN}

Tahapan Evaluasi Program Ujian Akhir Semester (UAS) Virtual di Perguruan Tinggi IAINU Kebumen Tahun Akademik 2019/2020.

Evaluasi program Ujian Akhir Semester (UAS) Virtual adalah suatu proses mengumpulkan, menganalisis, mengolah dan menyajikan data secara sistematis dari proses pelaksanaan UAS Virtual yang diukur berdasarkan kriteria dan standar yang telah ditetapkan untuk memberikan informasi sejauh mana tujuan program terlaksana dan dapat digunakan sebagai dasar pengambilan keputusan. Konsekuensi dari adanya Revolusi Industri 4.0, Perguruan Tinggi IAINU Kebumen sadar bahwa peristiwa tersebut dapat mengancam eksistensinya jika tidak segera melakukan perubahan dan berusaha untuk beradaptasi dengan adanya Revolusi Industri 4.0. Berdasarkan permasalahan tersebut, Perguruan Tinggi IAINU Kebumen telah merancang Rencana Strategis (Renstra) yang digelar pada 
hari Minggu, 24 November 2019 di Meotel Dafam Hotel, di Jalan Ahmad Yani, Kebumen. Salah satu bagian dari implementasi visi virtual di Perguruan Tinggi IAINU Kebumen adalah program UAS virtual. tahapan-tahapan evaluasi program yang dilakukan meliputi:

1. Tahap Perencanaan Evaluasi Program

2. Pelaksanaan Evaluasi Program

3. Tahapan Monitoring Pelaksanaan Evaluasi Program

4. Tahapan Analisis Data Penafsiran

5. Tahapan Penyusunan Rekomendasi

\section{Analisis Hasil Evaluasi Program Ujian Akhir Semester (UAS) Virtual di Perguruan Tinggi IAINU Kebumen Tahun Akademik 2019/2020.}

Penelitian ini merupakan penelitian evaluasi dengan statistik deskriptif. Tujuan dari penelitian ini adalah untuk mengetahui efektifitas dan efisiensi dari pelaksanaan UAS virtual dengan cara mengevaluasi pelaksanaan UAS virtual di Perguruan Tinggi IAINU Kebumen dilihat dari kesesuaian Context Evaluation, Input Evaluation, Process Evaluation, Product Evaluation dan secara keseluruhan. Data yang diperoleh dari hasil penelitian terhadap sampel penelitian ini diuraikan dalam bentuk tabel. Panduan lembar kuesioner terdiri dari 28 pertanyaan yang menggambarkan konteks, masukan, proses dan hasil dari program UAS virtual. Panduan lembar kuesioner ini disusun berdasarkan lembar kisi-kisi pengembangan instrumen, dengan item pilihan sangat baik, baik, kurang baik, tidak baik dan sangat tidak baik yang hanya dapat dijawab sesuai dengan keadaan nyata di lapangan. Berdasarkan analisis reliabilitas dengan menggunakan rumus Alpha dengan kriteria pengujian $r_{\text {hitung }}>r_{\text {tabel }}$ yang harga kritiknya 0,7 sudah dapat dikatakan reliabel tersebut memperoleh nilai dengan rata-rata 0,86 tergolong kategori sangat tinggi. Hasil dari analisis validitas dan reliabilitas tersebut dapat memperkuat evaluasi yang telah terlaksana.

\section{Evaluasi Context}

Jumlah butir yang ada pada kuesioner variabel context terdapat 7 pernyataan dengan menggunakan skala likert 5 alternatif jawaban yang bersifat positif dan negatif. Jawaban (SB) Sangat Baik, (B) Baik, (KB) Kurang Baik, (TB) Tidak Baik dan (STB) Sangat Tidak Baik. Berikut ini tabel jumlah skor perolehan jawaban responden pada instrumen variabel context. 


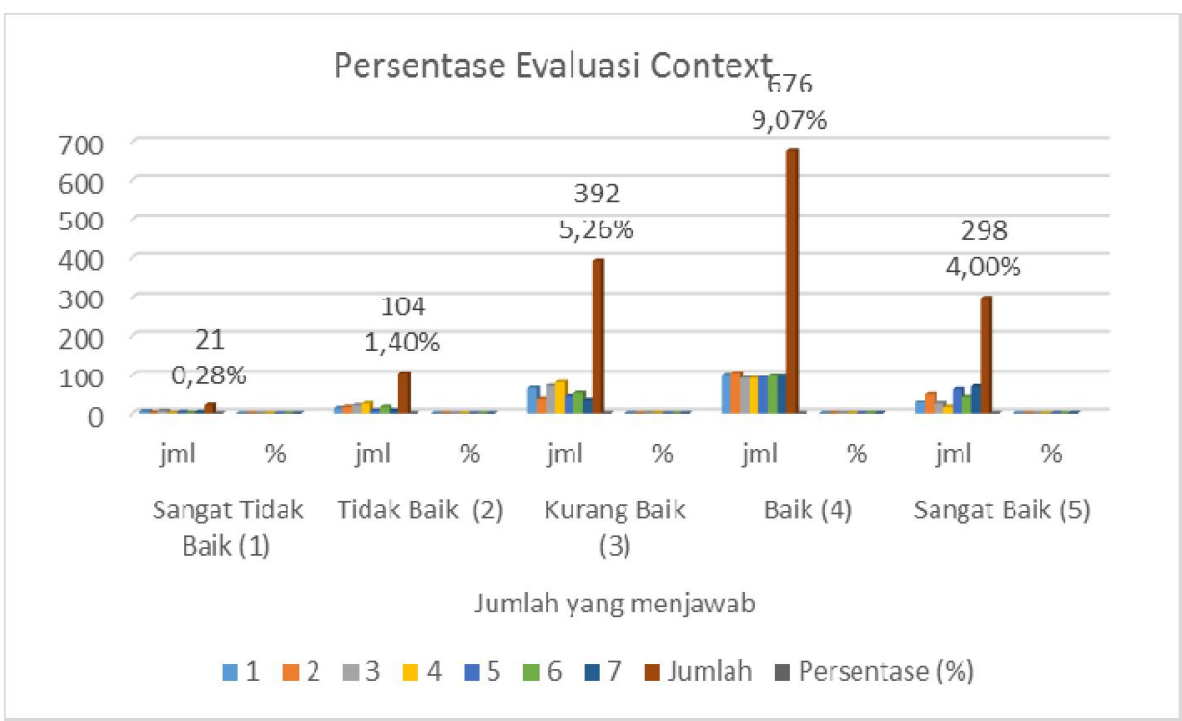

Berdasarkan tabel analisis instrumen variabel context dengan metode deskriptif presentase, diperoleh persentase dengan total keseluruhan skor $75,20 \%$ tergolong dalam kategori "Baik". Berdasarkan tabel juga dapat dilihat bahwa responden cenderung memilih alternatif jawaban ke empat yaitu baik. Pernyataan poin pertama yaitu kesesuaian program yang diberlakukan dengan harapan mahasiswa peserta UAS virtual. Pernyataan tersebut berkaitan dengan pemenuhan kebutuhan program. Berdasarkan data hasil kuesioner tersebut bahwa $46,95 \%$ responden menjawab baik dan 30,99\% menjawab kurang baik. Peneliti menyimpulkan bahwa program UAS virtual sesuai dengan harapan mahasiswa.

Poin ke dua dalam kuesioner dengan pernyataan kesesuaian program yang diberlakukan sesuai dengan teknologi saat ini. Pernyataan tersebut berkaitan dengan latar belakang adanya program. Tanggapan dari mahasiswa terhadap poin tersebut yaitu 49,30\% menjawab baik, kemudian $23,94 \%$ menjawab sangat baik sedangkan ada $18,31 \%$ menjawab kurang baik. Berdasarkan data tersebut, peneliti menyimpulkan bahwa mahasiswa sepakat dengan adanya UAS virtual sebagai upaya Perguruan Tinggi untuk terampil dalam menggunakan teknologi.

Poin ke tiga dalam kuesioner dengan pernyataan kesesuaian program dengan kebutuhan mahasiswa saat ini. Pernyataan tersebut berkaitan dengan kebutuhan yang belum terpenuhi. Pada pernyataan dalam poin tersebut mahasiswa sebanyak 42,72\% menjawab baik dan 33,33\% menjawab kurang baik. Menurut peneliti berdasarkan data tersebut mahasiswa terbantu dengan adanya UAS virtual, karena lebih efektif waktu dan efisien biaya untuk datang ke Kampus atau Perguruan Tinggi. Bagi mahasiswa ekstensi mereka merasa terbantu dengan adanya UAS virtual. Terdapat 16,43\% mahasiswa ekstensi yang mengisi kuesioner ada satu yang berpendapat bahwa ia sangat mendukung adanya UAS virtual supaya mahasiswa menjadi lebih kreatif dan terampil sesuai dengan zamannya yaitu zaman teknoogi digital. 
Poin ke empat pada kuesioner dengan pernyataan keterterimaan program pada pengguna secara umum. poin tersebut berkaitan dengan indikator karakteristik pengguna. Respon mahasiswa sebanyak 42,72\% menjawab baik, 37,56\% menjawab kurang baik. Berdasarkan data tersebut bahwa mahasiswa mayoritas menerima program UAS virtual untuk diterapkan.

Poin ke lima pada kuesioner dengan pernyataan memudahkan mahasiswa dalam melaksanakan UAS. Poin tersebut berkaitan dengan indikator keberadaan program di lingkungan mahasiswa. Mahasiswa merespon baik dengan persentase $44,13 \%$, selanjutnya $29,58 \%$ mahasiswa merespon sangat baik dan 25,35\% merespon kurang baik. Berdasarkan data tersebut, mayoritas mahasiswa merasa terbantu dengan adanya UAS virtual.

Poin ke enam pada kuesioner dengan pernyataan minat mahasiswa mengikuti UAS virtual. Mahasiswa merespon baik dengan persentase $46,01 \%$, kemudian $20,66 \%$ respon sangat baik sedangkan $25,35 \%$ dari mahasiswa merespon kurang baik. Mahasiswa yang mendukung tercapainya visi virtual mereka merespon baik dan sangat baik, sedangkan yang menjawab kurang baik, mereka mendukung akan tetapi harus disertakan dengan fasilitas yang memadai.

Poin ke tujuh pada kuesioner dengan pernyataan kesesuaian program UAS virtual dengan visi virtual IAINU kebumen. Mahasiswa merespon baik dengan persentase $45,54 \%$ dan merespon sangat baik dengan persentase $32,86 \%$. Berdasarkan data tersebut, mahasiswa menilai bahwa program UAS virtual memang sesuai dengan visi virtual IAINU Kebumen.

\section{Evaluasi Input}

Jumlah butir yang ada pada kuesioner variabel input terdapat 7 pernyataan dengan menggunakan skala likert 5 alternatif jawaban yang bersifat positif dan negatif. Jawaban (SB) Sangat Baik, (B) Baik, (KB) Kurang Baik, (TB) Tidak Baik dan (STB) Sangat Tidak Baik. Berikut ini tabel jumlah skor perolehan jawaban responden pada instrumen variabel input. 


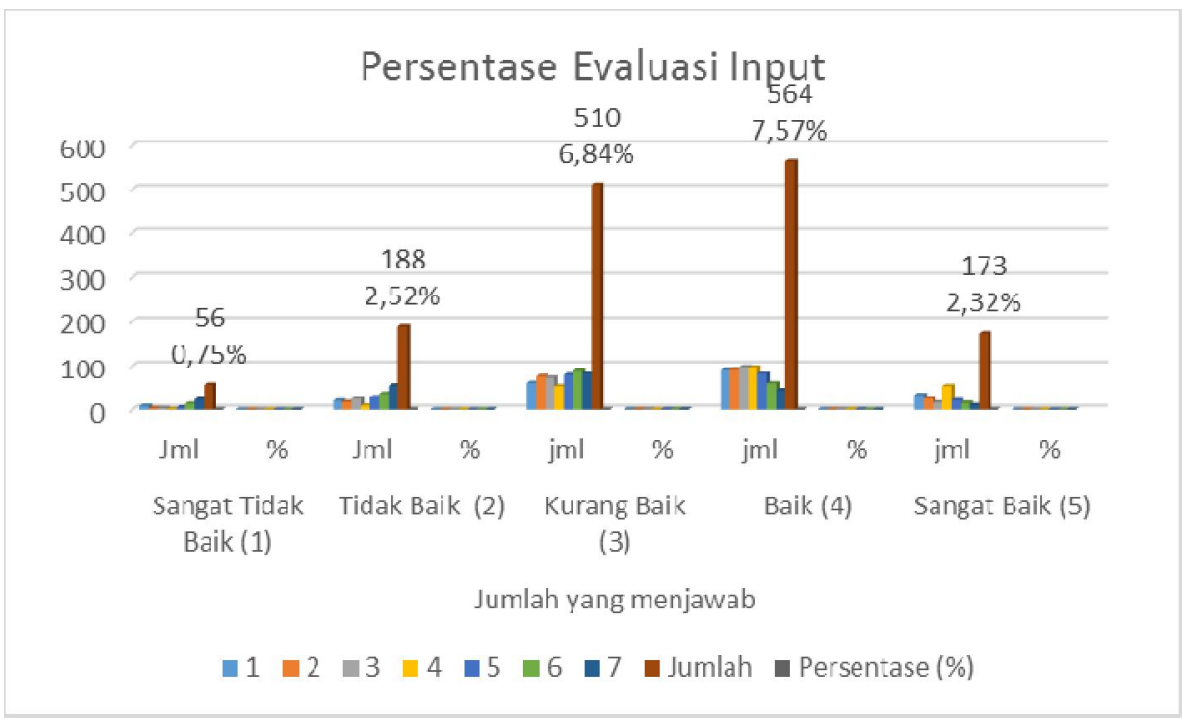

Berdasarkan tabel analisis instrumen variabel input dengan metode deskriptif presentase, diperoleh persentase dengan total keseluruhan skor $68,37 \%$ tergolong dalam kategori "Baik". Berdasarkan tabel juga dapat dilihat bahwa responden cenderung memilih alternatif jawaban ke empat yaitu baik, dan kurang baik. Selisih antara jawaban baik dan kurang baik tidak ada satu persen.

Poin ke satu pada kuesioner dengan pernyataan sosialisasi yang dilakukan sebelum pelaksanaan UAS virtual. Poin tersebut berkaitan dengan indikator rencana penyusunan program. Jumlah responden menjawab baik dengan persentase $43,19 \%$ dan yang menjawab sangat baik ada $15,49 \%$. Berdasarkan data tersebut responden merasa bahwa sosialisasi yang diberikan panitia UAS sudah baik.

Poin ke dua pada kuesioner dengan pernyataan simulasi pelaksanaan UAS virtual. Persentase responden yang menjawab baik sebanyak 43,66\% dan $11,74 \%$ menjawab sangat baik. Sementara, terdapat $35,21 \%$ dari responden menjawab kurang baik. Berdasarkan data tersebut, lebih dari $50 \%$ responden merespon baik sosialisasi yang dilakukan oleh panitia UAS virtual.

Poin ke tiga pada kuesioner dengan pernyataan kompetensi sumber daya manusia (SDM)/ panitia program dengan program. Responden sebanyak 46,01\% menjawab baik, sementara 33,80\% menjawab kurang baik dan $11,27 \%$ menjawab tidak baik. Penilaian tersebut jika dibandingkan dengan pernyataan dari panitia bahwa SDM bukan dari panitia saja tetapi, juga mahasiswa sudah mendapatkan pelatihan. Panitia menilai bahwa pelaksanaan kegiatan UAS virtual dapat terlaksana cukup baik. Berdasarkan perbandingan penilaian tersebut, SDM panitia UAS virtual sudah cukup baik.

Poin ke empat pada kuesioner dengan pernyataan mahasiswa mampu men-download dan meng-upload soal sesuai dengan link yang tersedia. Poin tersebut berkaitan dengan kompetensi mahasiswa. Responden menjawab baik sebanyak 45,54\%, menjawab sangat baik sebanyak $24,88 \%$ 
sedangkan yang menjawab kurang baik sebanyak 24,88\%. Berdasarkan data tersebut hampir dari $25 \%$ mahasiswa peserta UAS menjawab kurang baik. Hal tersebut disebabkan oleh kemampuan mahasiswa tidak sama dalam mengoperasikan aplikasi, sesuai pernyataan dari panitia UAS virtual.

Point ke lima pada kuesioner dengan pernyataan penyediaan sarana berupa jaringan internet Wifi di lingkungan kampus. Poin tersebut berkaitan dengan indikator sarana dan prasarana. Respon dari mahasiswa sebanyak 38,03\% menjawab baik, 9,86\% menjawab sangat baik dan $36,62 \%$ menjawab kurang baik. Respon kurang baik tersebut disertakan dengan harapan bahwa kualitas dari fasilitas Wifi harus ditingkatkan lagi dan responden berharap jangkauan Wifi untuk diperluas lagi. Padahal, Perguruan Tinggi sudah menambah akses internet pada lima titik dan menambah bandwith sebelum UAS virtual dilaksanakan. Berdasarkan penilaian dari responden, memang kekuatan jaringan internet harus ditingkatkan lagi.

Poin ke enam pada kuesioner dengan pernyataan kelancaran dan kecepatan wifi kampus untuk mengakses informasi. Poin tersebut berkaitan dengan indikator sarana dan prasarana. Responden menjawab $27,70 \%$ baik, 42,25\% kurang baik, 16,90\% tidak baik dan 7,04\% sangat baik. Berdasarkan data tersebut, sebagian besar responden merasa bahwa kecepatan akses internet di lingkungan kampus belum sepenuhnya cepat dan lancar serta wifi harus segera diperbaiki . Sementara, responden yang menjawab sangat baik kemungkinan mereka menggunakan wifi yang berada di area perpustakaan dan di area halaman kampus dekat masjid. Memang pada kedua titik tersebut jaringan wifi sangat kuat sehingga dapat mengakses informasi dengan lancar dan cepat.

Poin ke tujuh pada kuesioner dengan pernyataan efisiensi biaya UAS virtual yang harus dibayarkan mahasiswa. Poin tersebut berkaitan dengan indikator penganggaran dana program. Responden menjawab sangat tidak baik dengan persentase $10,80 \%, 25,35 \%$ tidak baik, 38,50\% kurang baik, $20,66 \%$ baik dan $4,69 \%$ sangat baik. Responden yang menjawab sangat tidak baik, tidak baik, dan kurang baik mereka mempunyai alasan yang sama yaitu untuk diberikan bantuan kuota dari Perguruan Tinggi. Mereka memandang bahwa biaya yang harus dibayarkan untuk UAS virtual sama jumlahnya dengan biaya yang harus dibayarkan untuk UAS secara offline. Sistem UAS yang berbeda mengakibatkan pemenuhan kebutuhan UAS juga berbeda. Pelaksanaan UAS secara offline membutuhkan kertas, sedangkan UAS secara virtual tidak membutuhkan kertas akan tetapi membutuhkan kuota internet. Kondisi tersebut membuat mahasiswa yang tidak memanfaatkan fasilitas wifi Perguruan Tinggi harus mempunyai kuota internet. Keadaan tersebut juga membuat mahasiswa harus mengeluarkan biaya tambahan untuk membeli kuota internet.

Berdasarkan kondisi tersebut, mahasiswa berharap kepada Perguruan Tinggi untuk memperhatikan kendala mahasiswa dari segi biaya. Ada yang berharap alokasi dana untuk membeli kertas dialihkan pada subsidi kuota untuk mahasiswa. Selain itu, mahasiswa juga berharap kalau tidak ada 
subsidi kuota internet paling tidak ada pengurangan biaya UAS virtual sehingga mahasiswa dapat membeli sendiri kuota internet yang mereka butuhkan untuk keperluan UAS virtual.

\section{Evaluasi Process}

Jumlah butir yang ada pada kuesioner variabel process terdapat 7 pernyataan dengan menggunakan skala likert 5 alternatif jawaban yang bersifat positif dan negatif. Jawaban (SB) Sangat Baik, (B) Baik, (KB) Kurang Baik, (TB) Tidak Baik dan (STB) Sangat Tidak Baik. Berikut ini tabel jumlah skor perolehan jawaban responden pada instrumen variabel process.

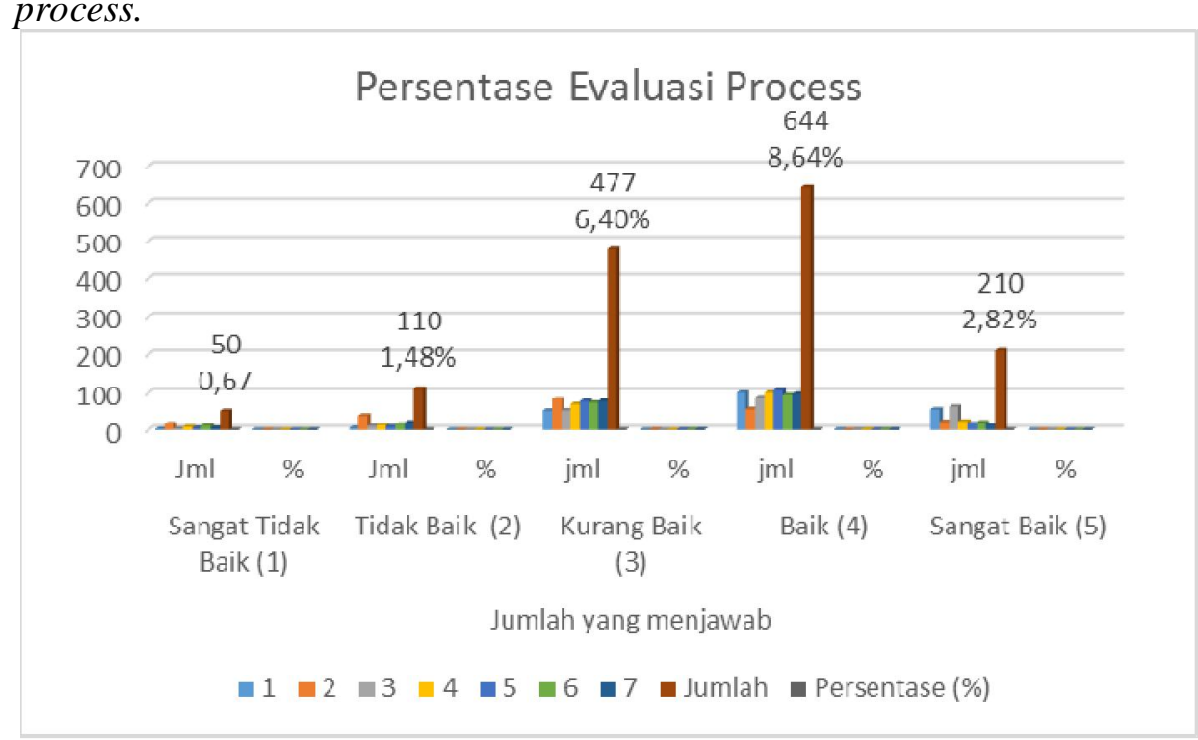

Berdasarkan tabel analisis instrumen variabel process dengan metode deskriptif presentase, diperoleh persentase dengan total keseluruhan skor 71,50\% tergolong dalam kategori "Baik". Berdasarkan tabel juga dapat dilihat bahwa responden cenderung memilih alternatif jawaban ke empat yaitu baik.

Poin ke satu pada kuesioner dengan pernyataan kesesuaian jadwal yang dibuat dengan pelaksanaan UAS virtual. Responden menjawab baik dengan persentase $47,42 \%$, menjawab kurang baik $23,94 \%$ dan menjawab sangat baik $25,35 \%$. Penilaian responden lebih dari $50 \%$ baik, sesuai dengan jadwal. Faktanya memang rencana dari pelaksanaan UAS virtual yang tercantum dalam Kalender Akademik IAINU Kebumen Tahun Akademik 2019/2020 jatuh pada tanggal 4-9 Januari 2020 dan sesuai dengan pelaksanaan. Jadi, berdasarkan data di atas pelaksanaan UAS virtual sudah sesuai dengan perencanaan yang tercantum dalam Kalender Akademik.

Poin ke dua pada kuesioner dengan pernyataan mahasiswa menggunakan wifi kampus untuk mengerjakan UAS virtual. Poin tersebut berkaitan dengan pemanfaatan sarana dan prasarana. Responden menjawab baik dengan persentase $25,82 \%$, menjawab sangat baik $10,33 \%$, menjawab kurang baik $38,50 \%$ dan menjawab tidak baik $17,84 \%$. Responden yang 
menjawab baik adalah responden yang menggunakan wifi kampus. Responden yang menjawab sangat baik yaitu responden yang menggunakan wifi kampus dan mereka terbantu dengan adanya wifi tersebut. Jadi mahasiswa lebih banyak yang tidak memanfaatkan fasilitas wifi kampus dibandingkan dengan yang datang ke kampus dan memanfaatkan wifi untuk mengerjakan UAS virtual.

Poin ke tiga pada kuesioner dengan pernyataan efektivitas waktu dalam mengerjakan UAS virtual. Responden menjawab baik dengan persentase $40,85 \%$, menjawab sangat baik $28,64 \%$, menjawab kurang baik $24,41 \%$ dan menjawab tidak baik 4,69\%. Berdasarkan data tersebut mayoritas dari responden merasa waktu yang digunakan untuk mengerjakan UAS virtual memang efektif. UAS virtual bisa dikatakan efektif waktu karena tidak memakan waktu untuk datang ke Perguruan Tinggi, bisa dikerjakan di mana saja tetapi dengan catatan jaringan internet yang digunakan harus lancar. Responden menjawab kurang baik disebabkan ada beberapa alasan, karena terhambat oleh sinyal yang kurang mendukung sehingga proses upload dan download memakan waktu lama. Terdapat soal yang error, sering keluar link sendiri dan soal yang memerlukan jawabab cukup panjang tidak sesuai dengan waktu yang tersedia. Menurut peneliti berdasarkan kondisi yang telah disebutkan di atas UAS virtual sudah cukup efektif. Hanya saja masalah-masalah yang muncul dari sistem harus segera diatasi.

Poin ke empat pada kuesioner dengan pernyataan kesanggupan panitia dalam memandu terlaksananya UAS virtual. Responden menjawab baik dengan persentase $47,42 \%$, menjawab sangat baik $10,80 \%$ dan menjawab kurang baik $31,92 \%$. Responden yang menjawab kurang baik disertai dengan beberapa alasan di antaranya yaitu responden berharap panitia cepat tanggap dalam menghadapi mahasiswa yang mengalami kesulitan dan mahasiswa yang ingin bertanya. Selain itu, salah satu mahasiswa peserta UAS virtual berharap bahwa informasi yang diberikan oleh panitia supaya disamakan, tidak ada perbedaan informasi antara panitia yang satu dengan lainnya. Berdasarkan data tersebut, responden menilai kesanggupan panitia dalam memandu terlaksananya UAS virtual sudah cukup baik.

Poin ke lima pada kuesioner dengan pernyataan mahasiswa mampu menyelesaikan hambatan dalam pelaksanaan UAS virtual. Responden menjawab baik dengan persentase 50,23\%, menjawab sangat baik 7,51\%, menjawab kurang baik 35,68\%, menjawab tidak baik $4,23 \%$ dan menjawab sangat tidak baik $2,35 \%$. Lebih dari $50 \%$ mahasiswa mampu menyelesaikan hambatan yang dijumpai saat UAS virtual. Selebihnya mahasiswa belum bisa menyelesaikan hambatannya dengan baik karena terkendala lemah sinyal, sering keluar link, jawaban UAS hilang padahal belum terkirim dan handphone tidak support. Dilihat dari usia input mahasiswa IAINU Kebumen tergolong generasi Y, jadi mengoperasikan teknologi digital bukanlah hal yang sulit bagi mereka. Berdasarkan realita tersebut, mahasiswa mampu menyelesaikan hambatan dalam pelaksanaan UAS virtual. 
Poin ke enam pada kuesioner dengan pernyataan respon panitia UAS virtual ketika mahasiswa menjumpai hambatan. Responden menjawab baik dengan persentase $44,60 \%$, menjawab sangat baik $9,39 \%$, menjawab kurang baik $33,80 \%$ dan menjawab tidak baik $7,0 \%$. Berdasarkan persentase dari data tersebut, penilaian responden terhadap panitia sudah cukup baik. Sementara, responden yang menjawab kurang baik karena mereka yang mengalami hambatan saat UAS virtual kemudian bertanya kepada panitia UAS akan tetapi menurut mereka kurang cepat dalam menanggapi.

Poin ke tujuh pada kuesioner dengan pernyataan solusi yang diberikan panitia UAS virtual saat mahasiswa menjumpai hambatan. Responden menjawab baik dengan persentase $46,01 \%$, menjawab sangat baik $6,57 \%$, menjawab kurang baik $35,68 \%$ dan menjawab tidak baik 9,39\%. Berdasarkan data tersebut, respon dari peserta UAS terhadap panitia UAS virtual sudah cukup baik. Respon yang baik kurang baik dan tidak baik, mereka berharap untuk ada peningkatan pelayanan saat UAS virtual berlangsung.

\section{Evaluasi Product}

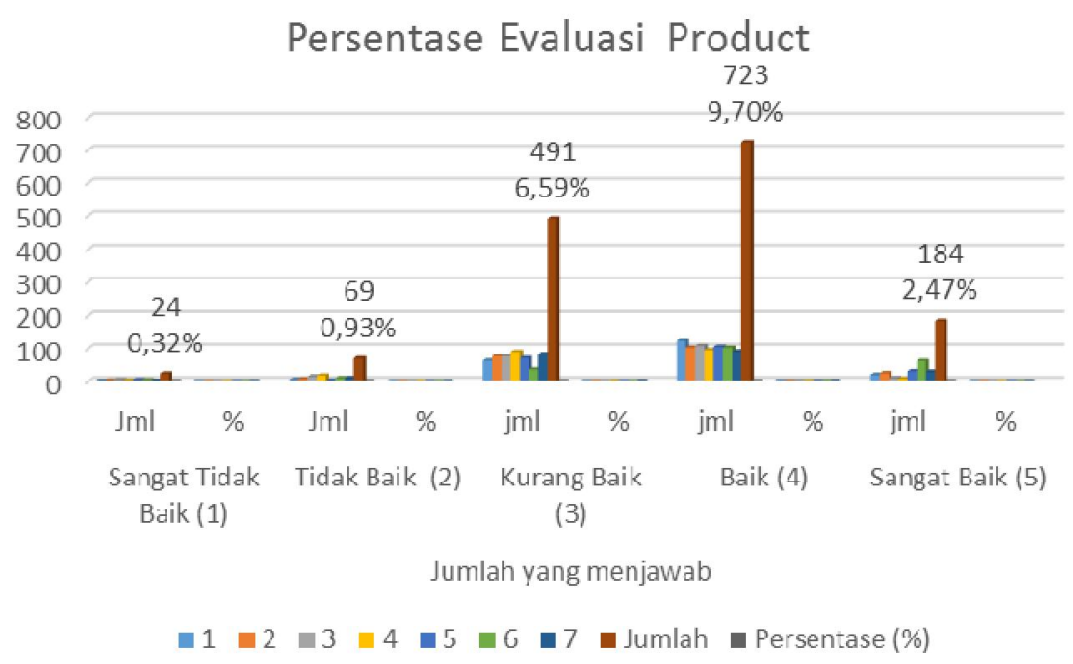

Berdasarkan tabel analisis instrumen variabel product dengan metode deskriptif presentase, diperoleh persentase dengan total keseluruhan skor $73,28 \%$ tergolong dalam kategori "Baik". Berdasarkan tabel juga dapat dilihat bahwa responden cenderung memilih alternatif jawaban ke empat yaitu baik.

Poin ke satu pada kuesioner dengan pernyataan hasil evaluasi berupa indeks prestasi kumulatif (IPK) lebih dari standar minimal. Poin tersebut berkaitan dengan pencapaian tujuan. Responden menjawab baik dengan persentase $57,75 \%$, menjawab sangat baik 9,39\%, menjawab kurang baik 29,11\%. Berdasarkan keterangan dari panitia UAS virtual bahwa IPK minimal 3,25 sesuai dengan pedoman akademik. Berdasarkan data di atas, hasil UAS virtual dari mayoritas peserta UAS virtual lebih dari IPK. 
Poin ke dua pada kuesioner dengan pernyataan manfaat yang diperoleh mahasiswa dari program UAS virtual. poin tersebut berkaitan dengan manfaat program yang dirasakan mahasiswa. Responden menjawab baik dengan persentase $47,89 \%$, menjawab sangat baik $11,74 \%$, menjawab kurang baik 3,29\%. Berdasarkan data tersebut, sebagian besar responden memperoleh manfaat dari adanya UAS virtual. Menurut komentar responden, dengan adanya UAS virtual ia berharap mahasiswa lebih cerdas dalam menggunakan teknologi. Selain itu, bagi peserta UAS virtual kelas ekstensi mereka sangat terbantu dengan adanya UAS virtual karena dapat lebih santai mengerjakan soal UAS virtual di rumah. Bagi yang menilai kurang baik, hal itu disebabkan karena mereka mengalami kendala saat UAS virtual.

Poin ke tiga pada kuesioner dengan pernyataan program UAS virtual sudah mencapai tujuan. Responden menjawab baik dengan persentase $50,23 \%$, menjawab sangat baik 4,69\% dan menjawab kurang baik 7,04\%. Tujuan dari UAS virtual adalah untuk membiasakan civitas akademika terkait teknologi sebagai media pelaksanaan evaluasi. Berdasarkan penilaian dari responden, tujuan program UAS virtual sudah cukup tercapai. Sama halnya dengan penilaian dari panitia UAS virtual, menurutnya tujuan UAS virtual cukup tercapai. Namun, di sisi lain sebenarnya sebagian mahasiswa mengeluhkan dengan adanya UAS virtual yang pengamanan jawabannya harus ditingkatkan lagi, karena mereka mengaku bahwa mereka dapat mencari jawaban dari google saat mengerjakan soal UAS virtual.

Poin ke empat pada kuesioner dengan pernyataan kualitas program UAS virtual. Responden menjawab baik dengan persentase 44,60\%, menjawab sangat baik 3,76\%, menjawab kurang baik 41,78\%, menjawab tidak baik $8,45 \%$. Berdasarkan data tersebut, kualitas program UAS virtual belum cukup baik. penyebabnya yaitu kurangnya sarana dan prasarana pendukung UAS virtual dan juga pelaksanaan UAS virtual baru perdana dilaksanakan dan sebelumnya memang belum terbiasa menggunakan media google classroom saat perkuliahan. Selain itu, kemampuan dari input peserta UAS juga berbeda-beda dalam mengoperasikan media digital dan smartphone yang belum support. Terlepas dari kekurangan tersebut, UAS virtual perdana sudah cukup terlaksana dengan baik.

Poin ke lima pada kuesioner dengan pernyataan kesuksesan program dalam memberikan kontribusi kepada kemajuan Perguruan Tinggi. Responden menjawab baik dengan persentase $48,83 \%$, menjawab sangat baik 14,55\% dan menjawab kurang baik 16,90\%. Berdasarkan data tersebut, bahwa responden memberikan penilaian yang baik terhadap program UAS virtual sebagai salah satu upaya mencapai visi virtual. Beberapa dari responden juga berharap dengan adanya UAS virtual IAINU dapat sebanding dengan kebanyakan kampus modern saat ini. Menurut peneliti, dengan adanya konsep dan gagasan untuk menjadi kampus atau Perguruan Tinggi virtual merupakan ide yang cemerlang. Perguruan Tinggi IAINU Kebumen sudah menerapkan UAS virtual maupun perkuliahan virtual sebelum Pandemi Covid-19 datang. Jadi, 
menurut peneliti program UAS virtual yang dilaksanakan sebagai langkah awal mewujudkan visi virtual untuk tahun 2029 sudah memberikan kontribusi kepada kemajuan Perguruan Tinggi.

Poin ke enam pada kuesioner dengan pernyataan mahasiswa menjadi terampil dalam menggunakan teknologi digital. Responden menjawab baik dengan persentase $47,89 \%$, menjawab sangat baik $28,64 \%$ dan menjawab kurang baik $16,90 \%$. Berdasarkan data tersebut, mayoritas dari responden menjawab baik. Adanya program UAS virtual tersebut menuntut mahasiswa untuk bisa menggunakan aplikasi-aplikasi yang dipakai sebagai media evaluasi. Sehingga, secara tidak langsung mahasiswa menjadi terampil menggunakan media digital karena sudah terbiasa.

Poin ke tujuh pada kuesioner dengan pernyataan dampak dari UAS virtual yang diharapkan oleh mahasiswa. Responden menjawab baik dengan persentase $42,25 \%$, menjawab sangat baik 13,62\% dan menjawab kurang baik $38,50 \%$. Responden yang menjawab kurang baik cukup banyak, hal itu disebabkan karena pengawasan saat pelaksanaan UAS virtual belum baik. Banyak yang mengeluhkan bahwa dengan adanya UAS virtual ini, mereka menjadi malas untuk berfikir karena dengan mudah dapat mengakses jawaban di google. Mahasiswa dapat dengan mudah meminta jawaban kepada teman. Keamanannya hanya dengan mengatur bahwa jawaban yang sudah terkirim sudah tidak dapat diedit lagi. Panitia UAS virtual juga mengakui bahwa terjadi plagiasi ketika peserta UAS mengerjakan soal. Menurut peneliti, teknis pengawasan UAS virtual memang harus segera diperbaiki.

\section{Evaluasi Secara Keseluruhan}

Berikut ini disajikan data hasil evaluasi UAS virtual dari keempat aspek yaitu aspek context, input, process dan product dengan menggunakan metode kuesioner untuk memperoleh data skundernya. Data tersebut diolah menggunakan rumus deskripsi persentase.

Tabel.1

Persentase Hasil Evaluasi

\begin{tabular}{|l|l|c|c|c|}
\hline No. & Aspek yang Dinilai & $\begin{array}{c}\text { Jumlah } \\
\text { Total Poin }\end{array}$ & Persentase & Kategori \\
\hline 1. & Evaluasi Context & 5606 & $75,20 \%$ & Baik \\
\hline 2. & Evaluasi Input & 5097 & $68,37 \%$ & Baik \\
\hline 3. & Evaluasi Process & 5330 & $71,50 \%$ & Baik \\
\hline 4. & Evaluasi Product & 5463 & $73,28 \%$ & Baik \\
\hline \multicolumn{2}{|l|}{ Evaluasi CIPP } & 21496 & $72,09 \%$ & Baik \\
\hline
\end{tabular}




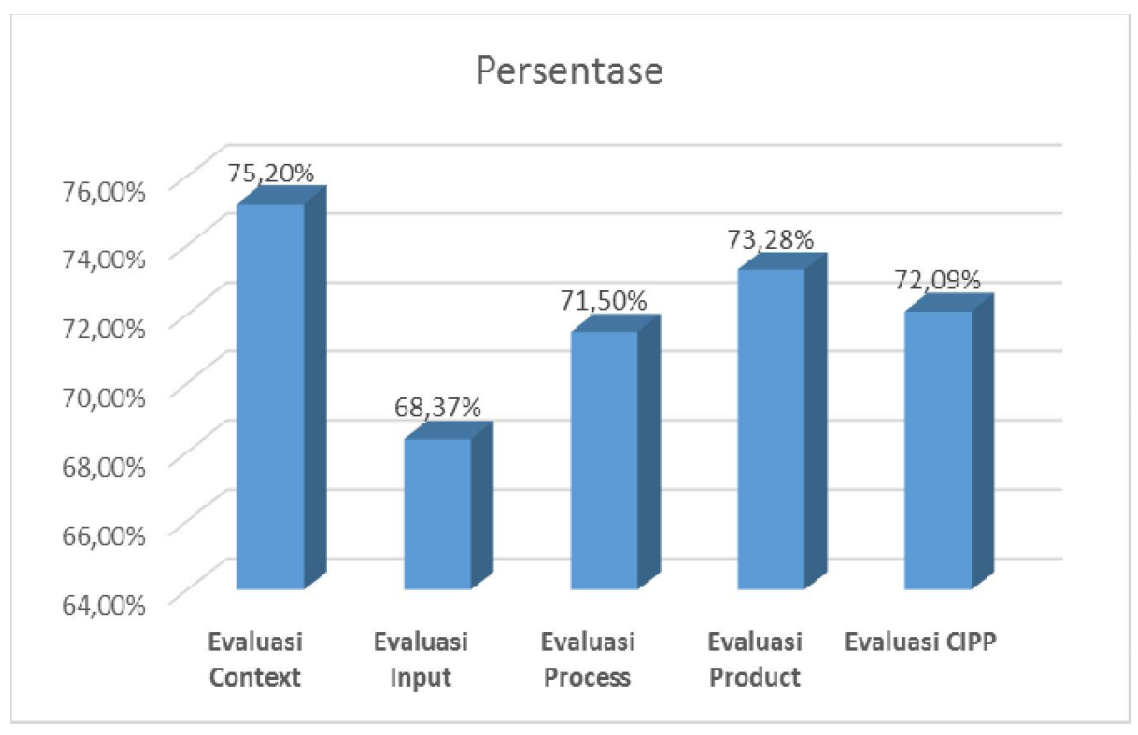

Analisis hasil evaluasi program UAS virtual Perguruan Tinggi IAINU Kebumen Tahun Akademik 2019/2020 termasuk dalam kriteria baik diperoleh dari data responden pada butir sub variabel 1 context dengan persentase $75,20 \%$, sub variabel 2 tentang input $68,37 \%$, sub variabel 3 tentang process dengan persentase $71,50 \%$, sub variabel 4 dengan persentase $73,28 \%$. Dilihat dari hasil deskriptif persentase, persentase yang didapatkan adalah 72,09\% dari keseluruhan aspek yaitu CIPP. Hasil tersebut sudah menunjukkan kriteria yang baik dan layak untuk diteruskan.

Setelah analisis selesai dilakukan, penulis menemukan dampak positif dan juga dampak negatif dari program UAS virtual. Berikut dampak positif dan dampak negatif dari program UAS virtual

a. Dampak Positif Program UAS Virtual

1) Mahasiswa menjadi terbiasa menggunakan media digital

2) Mahasiswa menjadi lebih terampil dalam teknologi digital

3) Pelaksanaan UAS lebih efektif waktu dan efisien biaya.

4) Dapat dikerjakan di mana saja, mudah dan cepat.

b. Dampak Negatif Program UAS Virtual

1) Terdapat plagiasi jawaban

2) Menjadi malas untuk berfikir

3) Peserta yang menjumpai hambatan teknis menjadi kurang nyaman

\section{PENUTUP}

\section{A. Kesimpulan}

Berdasarkan hasil penelitian dan analisis, maka kesimpulan yang dapat diambil dari penelitian ini yaitu:

1. Penulis melalui lima tahap dalam melaksanakan evaluasi program yaitu:

a. Tahap perencanaan evaluasi program

b. Tahap pelaksanaan evaluasi program

c. Tahap monitoring evaluasi program

d. Tahap analisis data penafsiran 
e. Tahap penyusunan rekomendasi

2. Berdasarkan analisis dari empat aspek CIPP (Context, Input, Process, Product), hasil analisis dapat disimpulkan sebagai berikut:

a. Aspek context, kesesuaian tujuan program yang disampaikan oleh pembuat program dengan penilaian termasuk kategori baik oleh mahaiswa sebagai responden dengan hasil persentase $75,20 \%$.

b. Aspek input, kesesuaian antara keadaan input yang disampaikan oleh pembuat program dan penyelenggara program dengan penilaian mahasiswa sebagai responden dengan hasil persentase $68,37 \%$ yang tergolong dalam kategori baik.

c. Aspek process, kesesuaian antara fakta proses pelaksanaan UAS virtual yang disampaikan oleh panitia dengan penilaian mahasasiswa sebagai responden dengan hasil persentase $71,50 \%$ yang tergolong dalam kategori baik.

d. Aspek product, kesesuaian antara pernyataan yang disampaikan oleh panitia UAS virtual mengenai hasil IPK dengan penilaian mahasiswa sebagai responden dengan hasil persentase $73,28 \%$ yang termasuk dalam kategori baik.

e. Keseluruhan aspek CIPP diperoleh persentase 72,09\% dengan kategori baik.

Jadi, beradasarkan data tersebut program UAS virtual dinilai sudah efektif dan efisien meskipun harus ada perbaikan peningkatan kualitas program untuk pelaksanaan selanjutnya.

\section{B. Rekomendasi}

Penelitian ini tidak menggambarkan pelaksanaan program UAS virtual secara mendalam, karena mengacu pada pertimbangan waktu dan biaya, penelitian ini masih dapat diperdalam lagi, rekomendasi untuk penelitian selanjutnya yaitu supaya responden yang diteliti lebih diperluas dengan cara memasukkan dosen dan staf yang terlibat dalam panitia UAS virtual untuk dijadikan sebagai responden. Selain itu, dokumen pendukung penelitian dapat dilengkapi lagi.

Berdasarkan harapan, kritik dan saran dari responden penulis menyampaikan rekomendari kepada pembuat keputusan. Rekomendasi tersebut yaitu:

1. Perguruan Tinggi dapat meningkatkan kembali sarana dan prasarana untuk menunjang pelaksanaan UAS virtual.

2. Perguruan Tinggi dapat meminimalisir terjadinya gangguan dalam sistem yang digunakan sebagai media UAS virtual.

3. Perguruan Tinggi dapat meningkatkan keamanan jawaban UAS virtual

C. Saran supaya tidak terjadi plagiasi.

Penulis dalam penelitian ini ingin menyampaikan saran-saran demi perbaikan dan kemajuan:

1. Bagi mahasiswa peserta UAS virtual hendaknya dapat meningkatkan kemampuannya supaya terampil dalam menggunakan teknologi digital supaya dapat mengatasi permasalahan dengan baik saat UAS virtual. 
2. Bagi Panitia pelaksana UAS virtual hendaknya dapat meminimalisir kemungkinan-kemungkinan hambatan yang terjadi dan dapat memberikan tanggapan dan solusi secepat mungkin.

3. Bagi Perguruan Tinggi hendaknya dapat meningkatkan sarana dan prasarana yang dibutuhkan dalam pelaksanaan UAS virtual supaya dapat terlaksana dengan baik dan lancar.

\section{Daftar Pustaka}

Ambiyar . \& D.Muharika. . (2019). Metodologi Penelitian Evaluasi Program. Bandung: Alfabeta.

Ananda, R \& Rafida, T. (2017). Pengantar Evaluasi Pendidikan. Medan: Perdana Publishing.

Arifin, Zainal. (2019). Evaluasi Program Teori dan Praktek dalam Konteks Pendidikan dan Nonpendidikan. Bandung: Remaja Rosdakarya.

May Oey-Gardiner, Mayling \& Dkk. (2017). Era Disrupsi Peluang dan Tantangan Pendidikan Tinggi Indonesia. Jakarta: Akademi Ilmu Pengetahuan Indonesia.hal.

Hujair AH Sanaky. Media Pembelajaran Interaktif-Inovatif. (Yogyakarta: Kaukaba Dipantara, 2013).

Munir. Pembelajaran Digital. (Bandung: Alfabeta, 2017).

Keputusan Rektor Pedoman Umum Pembinaan Organisasi Kemahasiswaan IAINU Kebumen tahun 2020 [

https://lektur.id/arti-ujian-akhir-semeser/\#Pengertian_Ujian_Akhir_Semester.

Diakses 4 Mei 2020 jam 07.33

https://v2.iainu-kebumen.ac.id/profill. Diakses 4 Mei 2020 jam 07.08.

https://pbingfkipunlam.wordpress.com/prosedur-operasional-standar/bab-v-ujianakhir-semester/ Diakses 9 April 2020, jam 08.11 